\title{
An Operational Algorithm for Residential Cogeneration Systems based on the Monitored Daily-basis Energy Demand
}

\author{
Yuka Yamagishi Student Member (Osaka Univercity) \\ Hideharu Sugihara Member (Osaka Univercity) \\ Osamu Saeki Member (Osaka Univercity) \\ Kiichiro Tsuji Member (Osaka Univercity)
}

Keywords: residential fuel cell, residential energy demand, energy conservation, economic evaluation

Residential co-generation system (CGS) with PEFC is expected to become a promising technology as distributed resources of power systems in order to improve energy system efficiency. However, it is important to develop efficient algorithm for operation because the energy demand at each house is largely different every day and there are technical or space restrictions for introducing PEFC cogeneration. In this paper, we propose the operational algorithm to make effective use of this system by forecasting energy demand profile at that house in advance and evaluate the algorithm at the point of energy conservation and economic index.

In this algorithm, there are three algorithms, called as "learning algorithm", "starting algorithm", "stopping algorithm". In the "learning algorithm", hot water and electrical demand on a next day is estimated by using average of the past data. In the "starting algorithm", we decide when we should start PEFC. First, we forecast three hot water demand at each time zone in a day by "learning algorithm". When we decided that estimated storage level in the tank at each time at that day cannot satisfy forecasted hot water demand at each time zone if we did not start PEFC now, we decide to start PEFC. During PEFC is operated, PEFC generates electricity following electrical load at the households because of improving economic index. We also estimate available exhaust heat for hot water demand by estimated electrical demand. The estimated exhaust heat are used to calculate when we should start and stop PEFC. Figure 1 shows a case of operation in this algorithm.

We simulated this proposal algorithm by using annual energy demand data of 20 houses that are actually measured by the authors. The 20 houses have various energy demand characteristics.

First, in order to compare with the proposed algorithm, we supposed an operation called as maximum energy saving potential and maximum economic potential respectively. At the maximum energy saving potential, the operation of PEFC are optimized at the point of energy conservation. The reduction of primary energy consumption at maximum energy saving potential is compared with annual electrical and hot water demand at each households to evaluate an influence of energy demand characteristics at each household. In the result, the larger heat/electricity ratio the household has, the larger reduction of primary energy consumption. By the same method, we considered at the point of economic index. At the maximum economical potential, the operation of PEFC are optimized at the point of economical index. As a result, the larger hot water demand the households has, the larger running cost saving rate.

Next, we evaluated attainments of this proposal algorithm at the point of energy conservation and economic index by the same

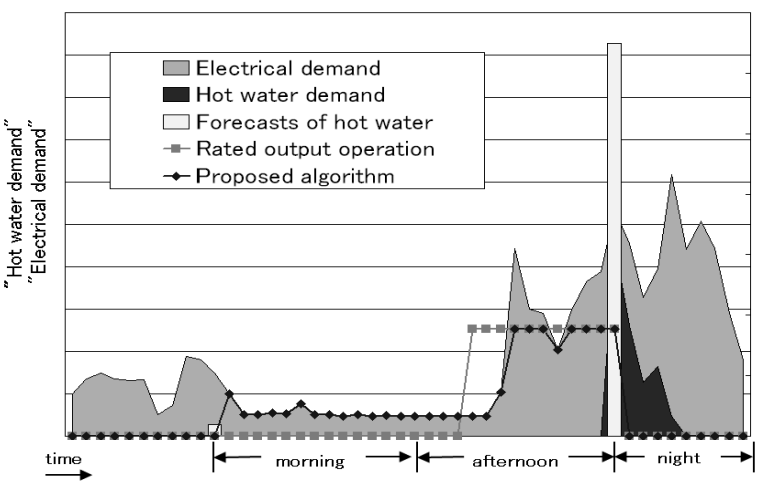

Fig. 1. Example of proposal algorithm

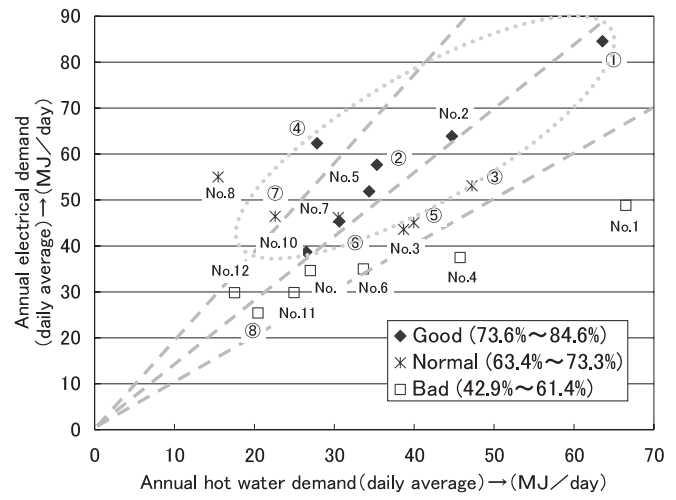

Fig. 2. Distribution of attainments for maximum energy saving potential

method of comparing with energy demand characteristics at each households. In Fig. 2, we classified households into three grade by attainments for maximum energy saving potential. By the distribution of attainments for maximum energy saving potential, the larger electrical demand the household has and the smaller heat/electricity ratio the household has, the larger attainments at the point of energy conservation. On the other side, by the distribution of attainments for maximum economical potential, the larger hot water demand the household has, the larger attainments at the point of economical index.

At this PEFC CGS, it was confirmed that this proposal algorithm is better than the operation in which we always get PEFC follow electrical load of the households at the point of energy conservation. 


\title{
日々のエネルギー需要実測データに基づく 住宅用コージェネレーションシステムの 運用手法に関する研究
}

\author{
学生員 山岸 由佳* 正 員 杉原 英治* \\ 正員佐伯 修* 正員辻 毅一郎*
}

\section{An Operational Algorithm for Residential Cogeneration Systems based on the Monitored Daily-basis Energy Demand}

Yuka Yamagishi*, Student Member, Hideharu Sugihara*, Member, Osamu Saeki*, Member, Kiichiro Tsuji*, Member

\begin{abstract}
Residential cogeneration system with PEFC is expected to become a promising technology as distributed resources of power systems in order to improve energy system efficiency. However, it is important to develop efficient algorithm for operation because the energy demand at each house is largely different every day. In this paper, we propose the operational algorithm and evaluate algorithm from view point of energy conservation and economic index based on the energy demand characteristics. In this algorithm, hot water and electrical demand on the next day is estimated based on the average of the past data. By using actually monitored energy demand data, the simulation results indicate that 1) the larger electrical demand a household has, the more efficient this algorithm become at the point of energy conservation 2) the larger hot water demand a household has, the more efficient this algorithm become at the point of economic index.
\end{abstract}

キーワード : 住宅用燃料電池, エネルギー需要, 省エネルギー, 経済性評価

Keywords: residential fuel cell, residential energy demand, energy conservation, economic evaluation

\section{1. はじめに}

近年，情報化や都市環境の高度化により都市部における 電力需要の高密度化が進展してきている。現在行われてい る大規模集中型の電力システムの場合，立地場所の関係か ら発電所の排熱を有効に利用することは困難である。そこ で, 住宅に分散型電源として燃料電池を設置し, 発電の際の 排熱を暖房や給湯用などの熱エネルギーとして利用しよう とするのが燃料電池コージェネレーションシステム $(\mathrm{CGS})$ である。この然料電池 CGS で用いられている固体高分子 型燃料電池 (PEFC) のセル本体は, 低温度で運転し, 起動 停止が容易で，小型化も容易であるなど，様々な長所を持ち 合わせているため，特に注目され開発が加速してきている。

一方，住宅におけるエネルギー需要は，業務用需要家と は異なり，時間的にも量的にも毎日変化していくため，こ のことを十分考慮した運用を行わなければならない。また,

\footnotetext{
* 大阪大学大学院工学研究科電気電子情報工学専攻

于 565-0871 吹田市山田丘 2-1

Dept. of electronic and information, Osaka Univercity

2-1, Yamadaoka, Suita 565-0871
}

PEFC を利用した住宅用 CGS の技術的な観点からは, 改質 器における起動停止エネルギーの消費や改質器の耐久性を 考えると頻繁に起動停止を行うことは困難であり, 併設さ れる貯湯槽は, 住宅における設置スペースの問題から,で きるだけ小さくすることが望まれる。PEFCを用いた住宅 用 CGS の普及に際して, 世带のエネルギー需要をまかな いつつ，このような技術的・スペース的な制約を考慮した 上での，効率的な運用アルゴリズムが必要不可欠である。

関連する既往の研究として文献(1)では, 実需要デー夕 に基づいて提案運転手法を適用した場合において, 省エネ ルギー性の面から導入効果を試算し, 文献 (3) では数種の 運転方法を様々な世帯の実測データに適用しているが，両 文献とも経済性の面からの評価は行われていない。その一 方で, 文献 (5) では標準住宅モデルを用いた電力・給湯負 荷データに対して数值シミュレーションプログラムを作成 し, 文献 (6) では PEFC 連続運転のもと, 実温水需要データ に基づいたシミュレーションによって，省エネルギー性・ 経済性両方の面からの考察が行われている。但し, 対象世 帯が数世帯に限られているため, 提案する運用アルゴリズ ムの一般的な結論が得られているとは言い難い。一般に経 
済性は導入に際して重要な指針となることが予想されるた め, 省エネルギー性を考慮しつつも, 経済性も重視した運 用アルゴリズムを提案し，シミュレーションによって評価 することが望まれる。

本論文は, 当日の電力負荷・給湯負荷を予測しながら運 用する学習型運転を用いてシステムの機器構成を総合的に 活かした運用アルゴリズムを提案し，実際に計測された 20 世带分の日々の需要变動デー夕に適用することで, 各世帯 のエネルギー需要特性と比較しながらどの程度の省エネル ギー性を達成可能であるかを評価することが目的である。 またそれと同時に，実際の導入に際して重要な経済性の面 からも評価を行い，イニシャルコストも含めた PEFC-CGS の導入可能性について考察する。

\section{2. 住宅用コージェネレーションの運用手法}

〈2・1〉 想定する住宅用 CGS 今回想定する住宅用 PEFC-CGS の構成を図 1 に示す。図中の数字は効率 (LHV) である。PEFC-CGS は従来の給湯器の代わりに設置され, 供給対象は給湯需要および電力需要のみとする。発電した 電力が需要に対し余剰となる場合は電力系統に売電するこ とが可能とし，貯湯槽に貯蔵されている温水が余剰となる 場合は廃棄することが可能とする。PEFC 本体の運転につ いては，基本的に起動と停止は一日に一回ずつ可能とする。 しかし，提案アルゴリズムにより連続運転すべきと判断さ れた場合や, 追加条件が有効と判断された場合は例外もあり うるとする。なお今回, 補助熱源として従来の容量 $30 \mathrm{~kW}$ のガス給湯器を設置するものとし, 湯切れは発生しないも のとする。

\section{〈2・2〉 PEFC 運用アルゴリズム}

（1）起動停止アルゴリズム 基本的には文献(1)の 起動停止アルゴリズムの考え方を用いる。まず，実際にシ ミュレーションを行った場合の運転の概念図を図 2 に示す。 この提案アルゴリズムでは 1 日を午前・午後・夜間の 3 つ の時間帯にわける。

- 午前-7:00 12:00

- 午後一12:00 予想お湯張り開始時刻

・夜間一予想扮湯張り開始時刻〜 (翌) 2:00

なお，この時間帯の区切りとして使われている「予想お湯 張り開始時刻」とは，過去の給湯需要データから，一日の

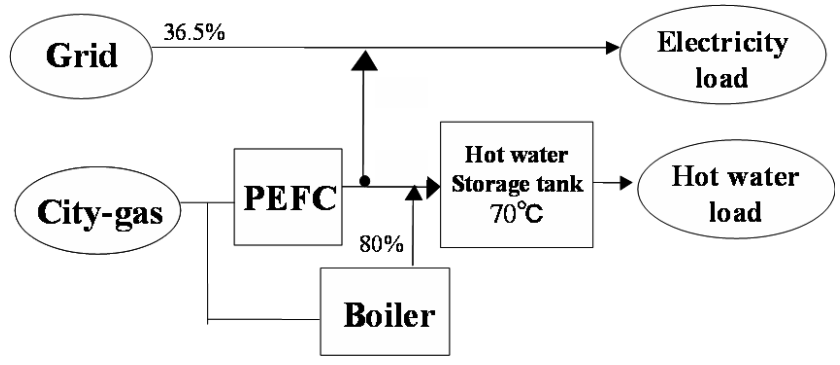

図 1 システム構成

Fig. 1. System configuration.
うちである一定以上の比較的大きな給湯需要が発生し始め る時刻を記録し，その平均時刻をとることで当日のお湯張 りが開始されると予想した時刻である。その他に，過去の 給湯需要データから当日の給湯需要を予測することで, 時 間帯ごとの予想給湯需要量を決定し，アルゴリズムで使用 する。

文献 (1) では給湯需要デー夕に基づき省エネルギー性を 評価しているが，本論文では世帯全体のエネルギー消費を もとに, 経済性も併せて評価する。そこで今回提案するア ルゴリズムにおいては経済性を考慮し, PEFCの運転中は 電力を出来る限り需要家内で消費できるように電力負荷追 従運転を行う。今回の対象データは 30 分おきのエネルギー 需要データであるため, 電力も過去の需要データから当日 の 30 分おきごとの電力需要を予測し, 当日の電力負荷追 従運転によって各時点で給湯に利用できる排熱量の予測も 行う。実際には PEFC は出力上昇時や下降時に出力変動速 度が存在するが，今回は考慮しないこととする。

まず，午前の時間帯が始まる7:00よりも前の時点におけ る起動条件としては, 現時点で PEFCを起動しなければ, 3 つの時間帯の開始時点 (7:00, 12:00, 予想お湯張り開始時 刻）において予想される貯湯量が, 各時間帯の予想給湯需 要量を下回ると判断された場合に起動するものとする。例 えば，2:00〜 7:00 までの時刻において，午前時間帯の開始 時点 (7:00) に予想される貯湯量は, 現時点の貯湯量と 7:00 までにPEFC から供給される給湯需要量の和から求めるこ とができる。PEFCは電力負荷追従運転を行うことを考慮 すると, 7:00 時点に対する起動判定条件は, 次式のように 表すことができる。今回の対象デー夕は 30 分おきのエネ ルギー需要データであるため, 30 分おきに起動を確認する こととする。

$$
H_{M} \geq S(t)+\sum_{\tau=t}^{T_{M}} p(\tau)
$$

但し, $H_{M}$ : 午前時間帯の予想給湯需要量, $p(t)$ : 予想電力需要量から求められる時点 $t$ における 30 分あたりの予想 PEFC 排熱量, $S(t)$ : 時点 $t$ にお

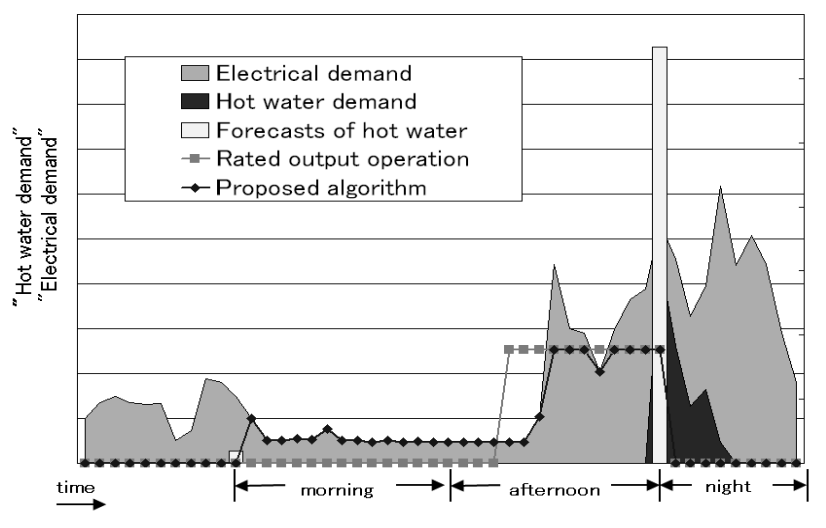

図 2 提案アルゴリズムの運用例

Fig. 2. Example of proposal algorithm. 
ける貯湯量, $T_{M}$ : 午前時間帯の開始時刻 (7:00)

午後および夜間の開始時刻の時点に対する起動判定条件 も，基本的には同様な考え方に基づき求めることができる。 但し，例えば 7:00よりも前の時点において夜間の開始時点 の貯湯量を予想するためには，午前および午後の給湯需要 量を予想する必要があり, 今回は前述の予想給湯需要量を 用いて夜間の開始時点の貯湯量を簡易的に予想するものと する。従って, 12:00 および予想お湯張り開始時刻に対する 起動判定条件は，それぞれ以下のように表すことができる。

$$
\begin{aligned}
& H_{A} \geq S(t)+\sum_{\tau=t}^{T_{A}} p(\tau)-H_{M} \cdots \cdots \\
& H_{N} \geq S(t)+\sum_{\tau=t}^{T_{N}} p(\tau)-H_{M}-H_{A}
\end{aligned}
$$

但し, $H_{A}$ : 午後時間带の予想給湯需要量, $H_{N}$ : 夜 間時間帯の予想給湯需要量, $p(\tau)$ : 予想電力需要 量から求める時刻 $\tau$ からの 30 分間あたりの予想 PEFC 供給熱量, $S(t)$ : 時点 $t$ における貯湯量, $T_{A}$ : 午後時間帯の開始時刻 $(12: 00), T_{N}$ : 夜間時間帯 の開始時刻（予想お湯張り開始時刻）

言い換えると，(3) 式の意味としては，午前と午後の給湯需 要量へ供給しつつ夜間の予想給湯需要量を満たすため, 現 時点 $t$ において PEFC を起動すべきかを判断することを表 している。

次に, 午前時間帯内における起動判定は, 7:00 以降のた め (1) 式は用いず，基本的に (2) 式および (3) 式を用いて判 定する。但し，起動判定をする時点において既に午前時間 帯の給湯需要の一部は発生しているため, 残りの時間であ とどれだけ給湯需要が発生するかを以下の式で予想し，(2) 式および(3) 式における $H_{M}$ の代わりに代入することで, 起 動判定を行うものとする。

$$
\begin{aligned}
& H_{M}^{\prime}(t)= \begin{cases}X(t) & \text { if }(X(t) \geq 0) \\
0 & \text { else }\end{cases} \\
& X(t)=H_{M}-\sum_{\tau=T_{M}}^{t} h(\tau) \cdots \ldots .
\end{aligned}
$$

但し, $h(\tau)$ : 時刻 $\tau$ の給湯需要, $T_{M}$ : 午前の時間 帯の開始時刻

さらに，午後の時間帯における起動判定も同様に，(3) 式 において， $H_{M}$ を 0 とし， $H_{A}$ を次式の $H_{A}^{\prime}$ に置き換えるこ とにより行うことができる。

$$
\begin{aligned}
& H_{A}^{\prime}(t)= \begin{cases}Y(t) & \text { if }(Y(t) \geq 0) \\
0 & \text { else }\end{cases} \\
& Y(t)=H_{A}-\sum_{\tau=T_{A}}^{t} h(\tau) \cdots \cdots
\end{aligned}
$$

最後に, 予想お湯張り開始時刻以降の夜間時間帯におけ る起動条件について, 夜間のような給湯需要の大きな時間
帯は給湯能力の高い補助熱源も併設しているため, このア ルゴリズム内で停止中の PEFC を起動することは行わない こととする。但し, 夜間でも後述の追加条件によって特別 に起動が行われることもある。

なお，現実には貯湯槽に熱損失が存在するが，本論文で は，単純かつロバストなアルゴリズムの開発を目的とする ため, 本起動停止アルゴリズムには考慮しないものとする。 但し, 後述のシミュレーション評価では, 貯湯槽における 蓄熱ロスを考慮して評価を行っている。

予想給湯需要量を設定しているため, その日の全ての時間 帯における予想給湯需要量を満たしたと判断したら PEFC を停止する。全ての給湯需要の発生をまたず先にPEFCを 停止させることで排熱の廃棄を最小限に抑え, 省エネルギー 性を高めることができる。

（2）学習アルゴリズム各時間帯の予想給湯需要量, 各時間の予想電力需要量を導き出すアルゴリズムを学習ア ルゴリズムとする。

今回は，単純に当該日の過去ある一定期間内に測定され た時間帯別の給湯需要量, 各時間の電力需要量の平均をと り, それをそれぞれの予想需要量とする。予想給湯需要量 は著者らの研究結果である文献(4)より平均をとる日数を 一週間にあたる 7 日間とし, 次式に示すように平均值の 1.5 倍を予想給湯需要量とする。係数 1.5 によってやや多めに 予想給湯需要量を見積もることで, 実際の給湯需要量が予 想給湯需要より多く見積もり, 出来る限り給湯需要を PEFC でまかない，省エネルギー性を向上させる。

$$
H_{T}=1.5 \frac{m_{1, T}+m_{2, T}+\cdots+m_{7, T}}{7}
$$

但し, $H_{T}$ : 時間帯 $T$ の予想給湯需要量, $m_{n, T}: n$ 日前の時間帯 $T$ の給湯需要量とする。

予想電力需要量についても同様に文献(4)を参考にし, 平 均をとる日数一週間にあたる 7 日間とし, 平均值の 1 倍を 予想電力需要量とする。つまり, 予想電力需要量は次のよ うに求めることとなる。

$$
E_{t}=\frac{e_{1, t}+e_{2, t}+\cdots+e_{7, t}}{7}
$$

但し, $E_{t}$ : 時間 $t$ の予想電力需要量, $e_{n, t}: n$ 日前 の時間 $t$ の電力需要量とする。

対象世帯では休日も含まれているため, 平日と休日を分け て平均をとることによって省エネルギー性や経済性が向上 するかどうかを一戸建ての世帯を対象に検討した。しかし 全ての世帯を平均して, 一次エネルギー削減率, 料金削減 率ともにほとんど変化がなかったため, 平日・休日を区別 せず平均した。

（3）起動停止に関する追加条件 今回提案するアル ゴリズムを適用するにあたって，排熱を有効利用すること を目的として, PEFCの起動停止に以下の追加条件を付加 する。

（i ）貯湯槽の蓄熱量が満杯になったら, PEFCの運転 
を停止する。

（ii）貯湯槽が空になり, 補助熱源が動き出した場合 PEFC を 1 日 1 回再起動する。

これらの条件はシミュレーションを通してその効果を実 証した。その使用頻度は付録 2 に示す。これらの条件をつ けるとほぼ全ての世帯で省エネルギー性がよくなり，同時 に経済性は悪化した。これは排熱を有効に利用できている 反面，満杯停止条件で PEFC を停止させてしまうため，経 済性が悪化したことによる。今回は省エネルギー性を優先 して全ての世帯において両追加条件を付加してシミュレー ションを行うこととする。

\section{3. 対象世帯のエネルギー需要特性}

本研究は著者らの研究グループで実測してきたエネルギー 消費デー夕の中から，京阪奈地域において，日々のデー夕 として利用可能な一戸建て住宅 8 軒, 集合住宅 12 軒の計 20 軒を対象世帯とする。デー夕は 30 分刻みで,一年間 365 日分である。図 3 に対象世帯の年間エネルギー消費量を, 表 1 に各世帯の属性を示す。一戸建て, 集合それぞれにわ けて年間エネルギー消費量の多い順に世帯番号をつけ，戸

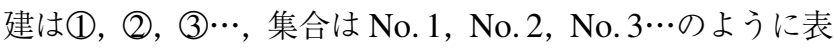
す。実際には集合住宅で灯油の消費も存在しているが，シ ミュレーション対象データとしていないため今回は省略す る。図 3 より全体的に幅広い年間エネルギー消費量をもっ

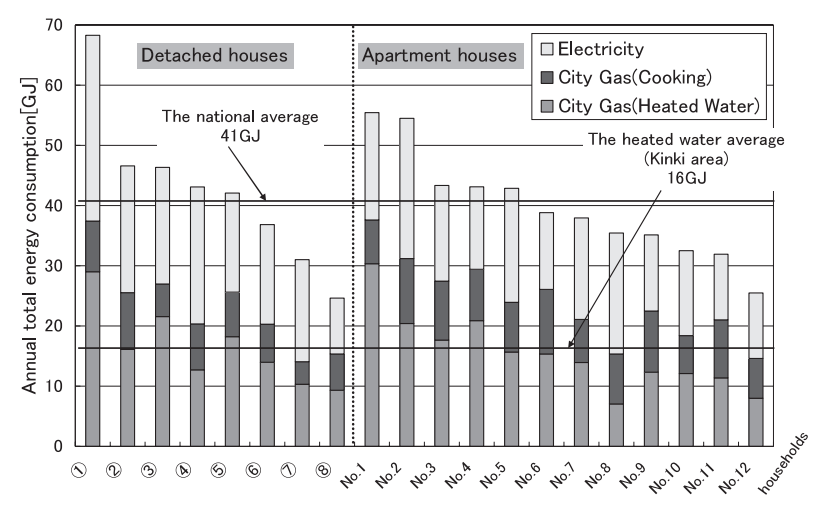

図 3 対象世帯の年間総エネルギー消費量

Fig. 3. Annual energy consumption of households.

表 1 各対象世帯の属性

Table 1. Attributes of households.

\begin{tabular}{|r|r|r|l|r|r|}
\hline & People & Floor space $\left(\mathrm{m}^{2}\right)$ & & People & Floor space $\left(\mathrm{m}^{2}\right)$ \\
\hline$(1)$ & 4 & 165 & No.1 & 5 & 92 \\
\hline$(2)$ & 4 & 122 & No.2 & 4 & 65 \\
\hline$(3)$ & 4 & 136 & No.3 & 4 & 78 \\
\hline$(4)$ & 4 & 130 & No.4 & 4 & 90 \\
\hline$(5)$ & 5 & 135 & No.5 & 4 & 78 \\
\hline 6 & 3 & 140 & No.6 & 4 & 99 \\
\hline$(7)$ & 4 & 120 & No.7 & 3 & 90 \\
\hline 8 & 2 & 135 & No.8 & 3 & 91 \\
\hline & & & No.9 & 4 & 84 \\
\cline { 3 - 6 } & & & No.10 & 4 & 80 \\
\cline { 3 - 6 } & & & No.11 & 3 & 85 \\
\cline { 3 - 6 } & & & No.12 & 4 & 76 \\
\cline { 3 - 6 } & & & & &
\end{tabular}

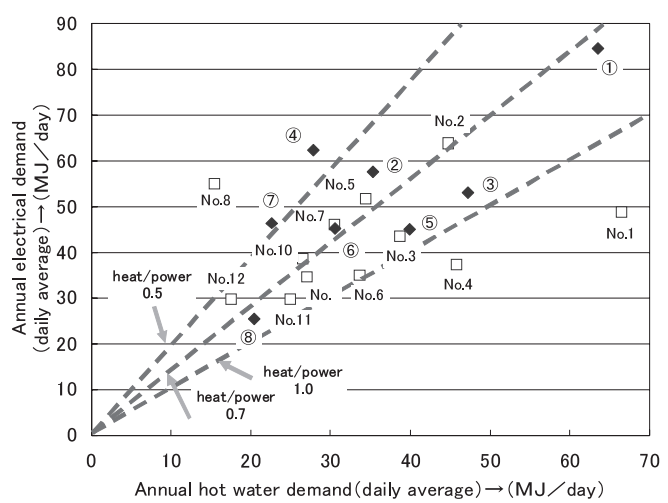

図 4 電力需要量と給湯需要量の相関

Fig. 4. Correlations of annual electrical demand and annual hot water demand.

た世帯のデータがあることがわかる。図 3 と表 1 を比較す ると, 延床面積が年間エネルギー消費量に大きく影響して いることがわかる。また, 実際のデータがどの程度の幅で 日々変化するのかを示すために，世带(1の 1 月と 2 月にお ける電力と給湯のエネルギー消費量を付録として例示する。

対象世帯毎に電力需要量と給湯需要量それぞれの日平均 の相関を図 4 に示す。この図の中の熱電比とは（給湯需要 ：電力需要）であり, 電力需要に対する給湯需要の割合で ある。多くの世帯は熱電比 $0.5 \sim 1.0$ に分布している。日本 建築学会実態調査データの世帯人数別全国平均(2)ではほぼ 熱電比 0.7 のラインに沿って世帯人数が増えるにしたがっ て, 電力・給湯需要量がともに増加しているが, それに対 して本研究の対象世帯データは 0.7 のラインを中心として 幅広く分布していることがわかる。

\section{4. 提案運用手法のシミュレーション}

〈4・1〉 シミュレーション条件 今回用いる電力・都 市ガスの料金体系を表 2 と表 3 に示す。全ての值において 消費税込みであるとする。都市ガス会社の都市ガスの料金 体系に関して, CGS を導入しないときは, 都市ガス会社の 「一般ガス供給約款」の料金を参考にし, CGS を導入した 場合は「家庭用コージェネレーションシステム契約」の料 金を参考に設定した。なお現在，住宅 CGS から系統への 売電は行われていないが，今回は現在行われている業務用 CGS から系統への売電価格を参考に，世帯から系統への売 電価格と仮定した。

エネルギー機器に関する設定值を表 4 と表 5 に示す。た だし，PEFCや貯湯槽容量は文献(3)において同世帯に対 して数々のシミュレーションを行った結果, 高い省エネル ギー性を示していた容量值を用いた。それによって PEFC 容量については, 図 3 に示されているように他世帯と比べ て年間総エネルギー消費量の多い 3 世帯に限り $1.0 \mathrm{~kW}$, 他 世帯は $0.7 \mathrm{~kW}$ となる。また今回はPEFCの部分負荷運転 も考慮しているため, 各出力值に対する部分負荷効率 (発 電，排熱）を表 5 に示す。 
表 2 電力価格に関する設定值

Table 2. Constants concerning with electricity.

\begin{tabular}{|c|c|c|c|}
\hline & $\begin{array}{c}\text { Jul-Sep } \\
\text { 8:00 22:00 }\end{array}$ & $\begin{array}{c}\text { Oct-Jun } \\
8: 00 \sim 22: 00 \\
\end{array}$ & $\begin{array}{c}\text { Jan-Dec } \\
\text { 22:00 8:00 }\end{array}$ \\
\hline $\begin{array}{c}\text { Unit cost, } \\
\text { Monthly unit cost } \\
{[\text { Yen } / \mathrm{kWh}, Y e n / k W} \\
\text { Yen } / \text { month }] \\
\end{array}$ & & $23,0,0$ & \\
\hline Selling price $[\mathrm{Yen} / \mathrm{kWh}]$ & 6.3 & 4.7 & 2.7 \\
\hline
\end{tabular}

表 3 ガス価格に関する設定值

Table 3. Constants concerning with city gas.

\begin{tabular}{|c|c|c|c|}
\hline & & Apr-Nov & Dec-Mar \\
\hline \hline $\begin{array}{c}\text { Unit cost, } \\
\text { Monthly unit cost } \\
{[\text { Yen/m3、Yen/month }]}\end{array}$ & $\begin{array}{c}\text { before } \\
\text { introducing CGS }\end{array}$ & \multicolumn{2}{|c|}{110,1200} \\
\cline { 2 - 4 } & $\begin{array}{c}\text { after } \\
\text { introducing CGS }\end{array}$ & 64,2000 & 80,2500 \\
\hline
\end{tabular}

表 4 エネルギー機器に関する設定值

Table 4. Constants concerning with energy equipments.

\begin{tabular}{|c|c|c|c|}
\hline & & (1), No1, No.2 & other \\
\hline \multirow{5}{*}{$\begin{array}{l}\text { PEFC } \\
\text { Unit }\end{array}$} & Capacity[kW] & 1.0 & 0.7 \\
\hline & $\begin{array}{c}\text { Temperature } \\
\text { of heated water }\left[{ }^{\circ} \mathrm{C}\right]\end{array}$ & \multicolumn{2}{|l|}{70} \\
\hline & Start up energy[Wh] & \multicolumn{2}{|l|}{600} \\
\hline & Shut down energy[Wh] & \multicolumn{2}{|l|}{225} \\
\hline & Waiting energy[W] & \multicolumn{2}{|l|}{10} \\
\hline \multirow{2}{*}{$\begin{array}{l}\text { Heated water } \\
\text { Storage Tank }\end{array}$} & Capacity[L] & \multicolumn{2}{|l|}{200} \\
\hline & Efficency $[\% / 30 \mathrm{~min}]$ & \multicolumn{2}{|l|}{99.7} \\
\hline \multirow{2}{*}{ Boiler } & Capacity[kW] & \multicolumn{2}{|l|}{30} \\
\hline & Efficency[\%] & \multicolumn{2}{|l|}{80} \\
\hline
\end{tabular}

表 5 PEFC の部分負荷効率 (LHV)

Table 5. Part-load efficiency of PEFC.

\begin{tabular}{|c|c|c|c|}
\hline Rated Output[W] & Output[W] & $\begin{array}{c}\text { Electrical } \\
\text { Generating } \\
\text { Efficinency[\%] }\end{array}$ & $\begin{array}{c}\text { Heat } \\
\text { Recorvery } \\
\text { Efficiency[\%] }\end{array}$ \\
\hline \multirow{4}{*}{1000} & 300 & 29 & 24 \\
\cline { 2 - 4 } & 500 & 31 & 33 \\
\cline { 2 - 4 } & 750 & 32 & 38 \\
\cline { 2 - 4 } 700 & 1000 & 33 & 41 \\
\hline \multirow{3}{*}{700} & 250 & 29 & 23 \\
\cline { 2 - 4 } & 500 & 32 & 34 \\
\cline { 2 - 4 } & 700 & 33 & 39 \\
\hline
\end{tabular}

〈4·2〉 シミュレーション結果 今回の提案アルゴリズ ムの達成度を評価するため, 比較対象として最大ポテンシャ ルを考える。最大ポテンシャルとはあらかじめ需要デー夕 が全て既知であり，一次エネルギー消費量やコストを最小 化するように運転パターンを決定した場合を指す。提案ア ルゴリズムの評価に用いる世帯ごとの PEFC 容量, 貯湯槽 容量，熱損失を考慮した上で，最適化プログラムを用いて 一次エネルギー削減量の最小化とコスト最小化の理想状態 をそれぞれ求めた。このとき用いたモデルを定式化したも のは付録 2 として記す。ただし最適化計算時間の関係から， この最大ポテンシャルにおいては，提案アルゴリズムのシ ミュレーションにおいて考慮されている部分負荷による効 率低下と起動停止エネルギーは考慮していないため, 現実 の最大ポテンシャルよりもやや大きめの值として算出され る。また，日々の起動停止回数に対する制約も考慮してい

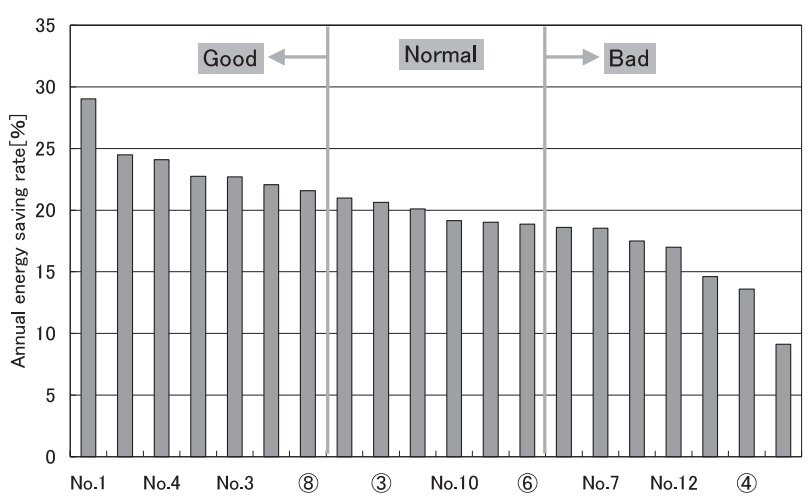

図 5 最大省エネルギーポテンシャルにおける 一次エネルギー削減率

Fig. 5. Reduction of primary energy consumption at maximum energy saving potential.

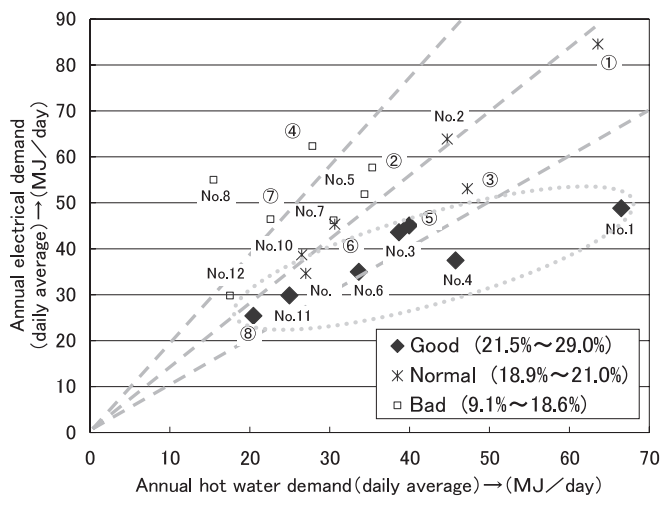

図 6 最大省エネルギーポテンシャルにおける 一次エネルギー削減率の分布

Fig. 6. Distribution of energy saving rate at maximum energy saving potential.

ない。

（1）オフライン最適化による最大ポテンシャル評価 まず，今回は対象世帯が 20 軒あるため, その中でもどの 世帯が住宅用 CGS に適しているかを最大ポテンシャルに よって評価する。省エネルギー性を最適化した最大省エネ ルギーポテンシャルにおける一次エネルギー削減率を図 5 に示す。ここで削減率の高い世帯から 7 軒, 低い世帯から 7 軒をそれぞれ good と bad とし, 残り 6 軒を normal と呼 ぶこととする。また，どのようなエネルギー需要特性をも つ世帯が省エネルギー性の面から優れているかを図 4 上で マーク分けしたものを図 6 に示す。図 6 からわかるように, 熱電比が大きい世帯ほど一次エネルギー削減率がよくなる 傾向がみられる。これは電力需要に対して給湯需要がある 程度大きければ，排熱が有効利用され省エネルギー性がよ くなることに起因している。

同様に，経済性を最適化した最大経済ポテンシャルにお ける料金削減額を図 7 に示す。全体的にばらつきはあるも のの, 給湯需要が多い世帯において料金削減額が多い傾向 がみられる。これは, 最大経済ポテンシャルにおいて基本 的に PEFC は電力需要に追従して運転を行うため, 結果的 


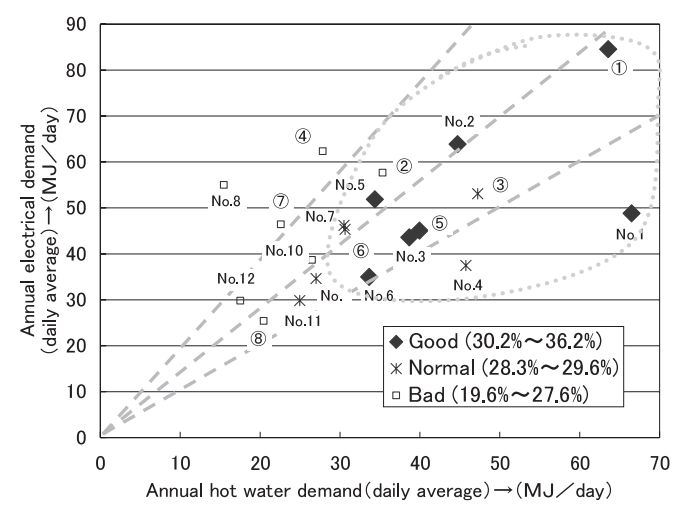

図 7 最大経済ポテンシャルに㧍ける料金削減率 の分布

Fig. 7. Distribution of running cost saving rate at maximum economical potential.

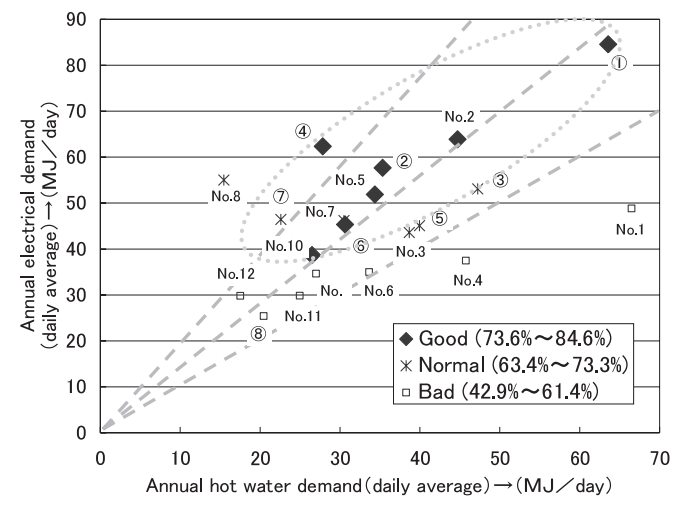

図 8 最大省エネポテンシャルに対する提案 アルゴリズムの達成度の分布

Fig. 8. Distribution of attainments for maximum energy saving potential.

に排熱を有効利用できるかどうかが料金削減額に影響して いるためと考えられる。また電力需要が多ければ定格出力 の大きいPEFC を導入しても，その定格出力を充分に活か して発電できるため，料金削減額も大きくなる。

(2) 提案アルゴリズムの評価次に最大ポテンシャ ルに対する本提案アルゴリズムの達成度を省エネルギー性・ 経済性の両面から評価する。まず，最大省エネルギーポテ ンシャルに対する提案アルゴリズムの一次エネルギー削減 量に扔ける達成度がどのようなエネルギー需要特性の世帯 で優れているかを図 8 に示す。分布からわかるように，達 成度は電力需要量の大きさに依存している傾向がある。こ れは本提案アルゴリズムに抏いては電力需要が多いと, 給 湯需要の多くにPEFC の排熱を利用できるためである。ま た給湯需要量に対して電力需要量が多い(熱電比が低い) 方 が達成度をよくしている。実際の運転に電力追従運転を用 いているため，多くの排熱が発生する熱電比の低い世帯が 提案アルゴリズムに適している。

最大経済ポテンシャルに対する提案アルゴリズムの料金 削減額における達成度の分布を図 9 に示す。この図からわ かるように, 給湯需要量が多い世帯ほど達成度が高い傾向

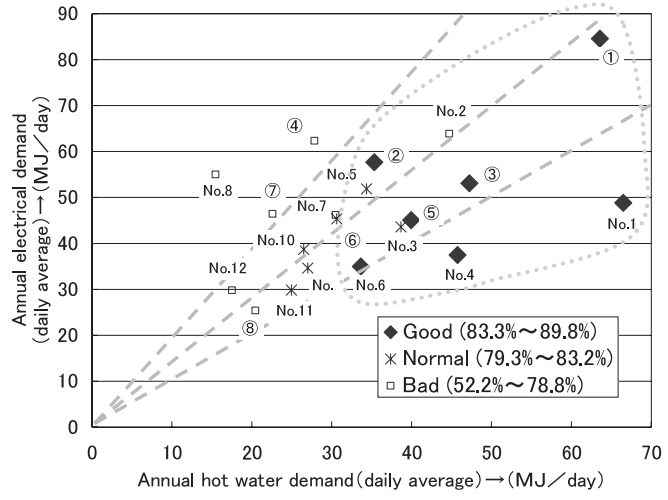

図 9 最大経済ポテンシャルに対する提案 アルゴリズムの達成度の分布

Fig. 9. Distribution of attainments for maximum economical potential.

が見られる。経済性は PEFC が電力需要量に追従して運転 する時間が長いほどよくなるが, 給湯需要量が多いとそれ を満たそうとして PEFC が長い間発電するため経済性がよ くなる。世带の需要特性を考慮したこれらの分析は, 省工 ネルギー性・経済性が低い世带に対してその性質を補うよ うに運用手法のきめ細かい条件を変更することなどに利用 できる。

ここで提案アルゴリズムによる省エネルギー効果を明確 にするため,「完全電力追従運転」との比較を行う。「完全電 力追従運転」とは, 予想給湯需要量に関係なく常に電力負 荷追従運転を行う運転方法である。この「完全電力追従運 転」と提案運用手法における省エネルギー削減率を図 10 に 示す。グラフからわかるように全ての世帯に扔いて，単純 に「完全電力追従運転」するだけでなく提案運用手法を用い ることで省エネルギー性の向上に役立っていることがわか る。世帯によってその効果は異なり，世帯 No. 1 の $0.2 \% の$ 向上から世带No. 8 のように省エネルギー削減率が $4.1 \%$ 向 上する場合もある。この向上は世帯 No. 8 の上うに給湯需 要量が少ない世带で大きい傾向がある。これは「完全電力 追従運転」を行うと, 給湯需要量が少ない世帯においては 特に多くの排熱が有効利用しきれず廃棄されてしまい，提 案アルゴリズムのようにPEFC の運転を制御することで省 エネルギー性が大きく向上するということを示している。

(3) 提案アルゴリズムに基づくイニシャルコストの分 析次に実際の導入に際して重要である経済性の面でよ り現実的な評価を行うため, 図 9 で用いられているものと同 じ結果の際の年間ランニングコスト削減額と最大経済ポテ ンシャルに対する提案アルゴリズムの達成度を併せて図 11 に示す。最大経済ポテンシャルにおける達成度とは, 各世 帯の最大経済ポテンシャルに扔ける料金削減額に対する, 各世带に提案アルゴリズムを適用したときの料金削減額の 割合を指す。

まず最大経済ポテンシャルに対する達成度をみると, 最低 でも世帯 No. 8 の約 52\%で，ほとんどの世帯で 70\%以上の 


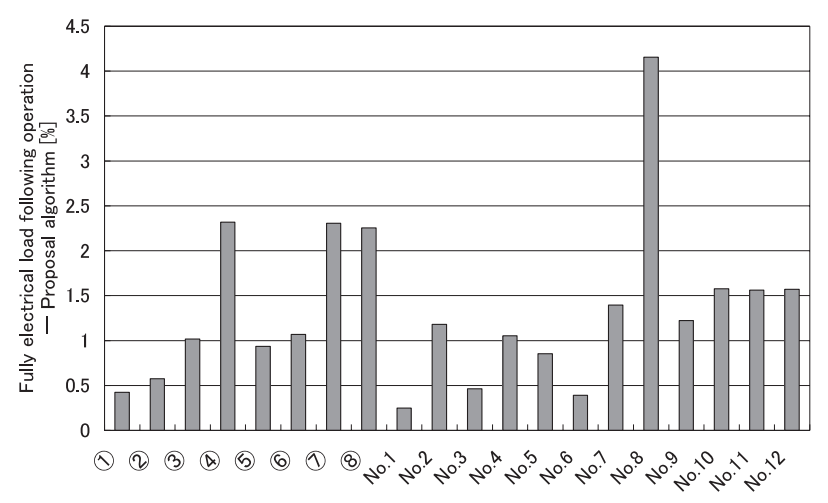

図 10 一次エネルギー削減率の比較（完全電力 追従運転からの改善率)

Fig. 10. Comparison at the point of energy-saving rate.

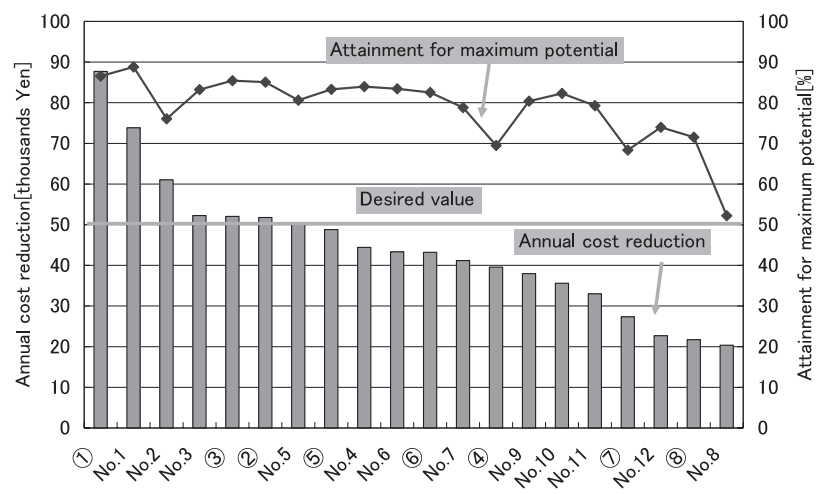

図 11 年間ランニングコスト削減額と最大経済 ポテンシャルに対する達成度

Fig. 11. Cost reduction and attainment for maximum economical potential.

達成度を示している。次にイニシャルコストを含めた評価 を行うため, PEFC-CGS の耐用年数を 10 年とすると, 今回 は総機器コストが $($ 年間ランニングコスト削減額 $\times 10)$ 円以 下であれば経済性の面からメリットがあることとなる。燃 料電池の実用化では 50 万円を目標としている ${ }^{(8)}$ ため, 年間 ランニングコスト削減額が 5 万円を超えている上位 7 世帯 以外の世带への導入には更に機器コストの低減が求められ る。逆に，機器コストの低減が見られないうちに PEFC CGS を導入する場合は，経済性の面からメリットを出すた めに予想給湯需要量以上に電力負荷追従運転させることも 考えられる。最後に，年間ランニングコスト削減額と比較 して最大経済ポテンシャルに対する達成度をみると，世帯 No. 10 や No. 9 またはその他数世帯で $80 \%$ 以上の達成度を 示しているのにもかかわらず，年間ランニングコスト削減 額は 4 万円以下となって㧍り，システムの機器コストを含 めた経済性の点からは導入の可能性が低いといえる。

\section{5. むすび}

本論文では，PEFC を用いた住宅用 CGS において，負荷 予測を行う学習運転を用いた運用手法を提案し，20 世带で 実測された日々のエネルギー需要デー夕に適用したシミュ
レーションを行い，世帯のエネルギー需要特性と比較しな がら省エネルギー性・経済性の面から評価, 検討した。本 論文によって得られた結論を以下にまとめる。

（1）対象世帯のエネルギー需要特性と最大ポテンシャ ルに扔ける一次エネルギー削減率や料金削減率の関係を検 討した結果，熱電比が高い世帯で省エネルギー性が高く， 給湯需要量の多い世带で経済性が高い傾向があることがわ かった。

（2）対象世帯のエネルギー需要特性と提案アルゴリズ ムの最大ポテンシャルに対する達成度の関係を検討すると, 電力需要量が多い世帯で省エネルギー性の達成度が高く, 給湯需要量の多い世帯で経済性の達成度が高くなることが わかった。

（3）提案アルゴリズムは常に電力追従運転を行った場 合と比べて，一次エネルギー削減率を $0.2 \% \sim 4.1 \%$ 上昇さ せ，この運用手法を導入することで排熱がより有効利用さ れることがわかった。

（4）提案アルゴリズムでは最大経済ポテンシャルの 52\%～90\%を達成した。ただしエネルギー需要が比較的少 ない世帯の中には，イニシャルコストも含めた場合実際に CGS の導入可能性が低い世带があることが分かった。

\section{謝 辞}

本研究は阪大フロンティア研究機構の環境システムプロ ジェクト「環境低負荷型ユーティリティシステムの創生」 (プロジェクトリーダー辻毅一郎教授)の一環として計測さ れたデータを用いている。計測調査に協力いただいた世帯, 並びに京阪奈地区の関係各位に謝意を表する。

(平成 19 年 3 月 13 日受付，平成 19 年 9 月 7 日再受付)

\section{文献}

(1) H. Sugihara, T. Kato, Y. Suzuoki, and K. Tsuji: "A Daily Start and Stop Algorithm for Residential Fuel Cell Systems considering Information Setting of Day-ahead Hot Water Demand", IEEJ Trans. PE, Vol.124, No.5, pp.705713 (2004-5) (in Japanese)

杉原英治・加藤丈佳 - 鈴置保雄 - 辻毅一郎 : 「翌日給湯負荷の情報 設定を考慮した住宅用燃料電池の起動停止アルゴリズム」, 電学論 B, 124, 5, pp.705-713 (2004-5)

(2) Institute for Building Environment and Energy Conservation: "Reports about the results of research on introducing residential fuel cells" (2006) (in Japanese)

(財) 建築環境・省エネルギー機構：住宅用燃料電池の導入に関する 技術研究成果報告会 (2006)

(3) K. Masumoto, K. Maeda, H. Akihito, and K. Takimoto: "Operation Control of Residential Gas Cogeneration System", Proc. of the 23rd Annual Meeting of Japan Society of Energy and Resources, pp.9-12 (2004) (in Japanese) 栘本幸嗣・前田和茂・早野彰人・滝本桂嗣：「家庭用ガスコージェネ レーションシステムの運転制御方法について」, 第 23 回エネルギー・ 資源学会研究発表会, pp.9-12 (2004)

(4) R. Inada, H. Sugihara, O. Saeki, and K. Tsuji: "Evaluation of Introducing Micro-Cogeneration System to Residential Houses Based on the Monitored Daily-Basis Energy Demand Data”, Proc. of the 22nd Conference on Energy, Economy, and Enviroment (2006) (in Japanese)

稲田 亮・杉原英治・佐伯 修・辻毅一郎：「実測デー夕に基づく 日々のエネルギー需要変化を考慮した住宅用コージェネレーション の導入評価」第 22 回エネルギーシステム・経済・環境コンファレ ンス (2006)

(5) H. Kuroki, S. Shimizu, H. Takagushi, and T. Watanabe: "Effective Operation Methods and Energy Conservation Effect of Housing Polymer Electrolyte 
Fuel Cell Co-generation Sysytems", J. Environ. Eng., AIJ, No.610, pp.6773 (2006-12) (in Japanese)

黒木 洋·清水章太郎·高口洋人·渡辺俊行: 「家庭用固体高分子型燃 料電池 CGS の運転方法と導入効果」, 建築学界環境系論文集, No.610, pp.67-73 (2006-12)

(6) T. Kato, N. Hino, S. Kasugai, and Y. Suzuoki: "Economic Assessment of Home Co-generation Syetem with PEFC based on Survey of Hot-water Demand", IEEJ Trans. PE, Vol.123-B, No.12, pp.1513-1520 (2003-12) (in Japanese)

加藤丈佳・日野紀良・春日井志織・鈴置保雄 : 「温水需要の実測に 基づく住宅用コージェネレーションシステムの経済性評価」, 電学論 B, 123, 12, pp.1513-1520 (2003-12)

(7) Y. Yamagishi, H. Sugihara, O. Saeki, K. Tsuji, and S. Kawasaki: "An operational algorithm for Residential cogeneration system Based on the Monitored Daily-Basis Energy Demand", Proc. of the 25th Annual Meeting of Japan Society of Energy and Resources, pp.223-226 (2008) (in Japanese) 山岸由佳・杉原英治・佐伯 修·辻毅一郎：「日々のエネルギー需要 実測データに基づく住宅用コージェネレーションシステムの運用手 法」, 電力技術 ·電力系統技術合同研究会, pp.223-226 (2006)

(8) A Study Group Working on Strategy for Fuel Cell Commercialization: A Report of Study Group Working on Strategy for Fuel Cell Commercialization (2001) (in Japanese)

燃料電池実用化戦略研究会 : 燃料電池実用化戦略研究会報告 (2001)

\section{付録}

\section{1. 電力・給湯消費量の日毎の変化}

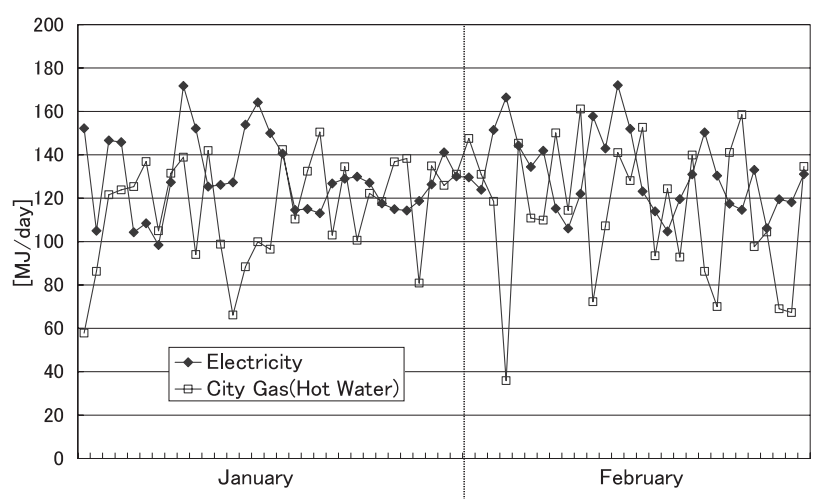

付困 1 電力・給湯消費量における日毎の変化（戸建(1) app. Fig. 1. Change in electricity and hot water consumption Day by day.

\section{2. 最大ポテンシャルを求めるモデルの定式化}

〈一次エネルギー消費量, ランニングコストの算出式〉

$$
\begin{aligned}
Y_{p r i}= & \sum_{d, t}\left(E_{d, t}^{G} \cdot p_{d, t}+G_{d, t}^{P}+G_{d, t}^{B}+G_{d, t}^{C}\right) \cdots \cdots(\text { 付 } 1) \\
Y_{\cos t}= & \sum_{d, t}\left\{E_{d, t}^{G} \cdot c_{d, t}^{E}+\left(G_{d, t}^{P}+G_{d, t}^{B}+G_{d, t}^{C}\right) \cdot c_{d, t}^{G}-E_{d, t}^{\text {sell }} \cdot c_{d, t}^{E s e l l}\right\} \\
& \left.+C_{m}^{E}+C_{m}^{G} \ldots \ldots \ldots \ldots \ldots \ldots \ldots \ldots \text { (付 } 2\right)
\end{aligned}
$$

[外生変数]

$c_{d, t}^{E}, c_{d, t}^{G}$ : 電力 $\cdot$ 都市ガスの従量料金, $C_{m}^{E}, C_{m}^{G}$ : 電力 $\cdot$ 都市ガスの基本料金, $p_{d, t}$ : 一次エネルギー換算係数 [内生変数]

$E_{d, t}^{G}$ : 系統からの発電量, $G_{d, t}^{P}, G_{d, t}^{B}, G_{d, t}^{C}: \mathrm{PEFC}$, 補 助ボイラ, 嘚房での都市ガス消費量

[添字・肩字 $]$

$m:$ 月, $d:$ 日, $t:$ 時刻, $E$ : 購入電力, $G:$ 都市ガス,
Esell: 販売電力, $P:$ PEFC, $B$ : 補助ボイラ, $C$ : 厨房 〈本モデルの目的関数と制約条件〉

[目的関数 $]$

$$
\min Y_{p r i} \text { or } Y_{\cos t}
$$

[制約条件]

$$
\begin{aligned}
\begin{aligned}
E_{d, t}= & \eta_{p_{e}} \cdot G_{d, t}^{P}+E_{d, t}^{G}-E_{d, t}^{s e l l} \ldots \ldots \\
H W_{d, t}= & \eta_{\tan k} \cdot T_{d, t-1}+\eta_{P_{h w}} \cdot G_{d, t}^{P} \\
& \quad-T_{d, t}-D_{d, t}+\eta_{B} \cdot G_{d, t}^{B} \ldots
\end{aligned} \\
\begin{aligned}
G_{d, t}^{P} \cdot \eta_{P_{e}} \leq \operatorname{Cap}^{P} \ldots \ldots \ldots \ldots \ldots \ldots \ldots \ldots \\
G_{d, t}^{B} \cdot \eta_{B} \leq \operatorname{Cap}^{B} \ldots \ldots \ldots \ldots \ldots
\end{aligned} \\
T_{d, t} \leq \operatorname{Cap}^{T} \ldots \ldots \ldots \ldots \ldots \ldots
\end{aligned}
$$

[外生変数]

$\eta^{*}$ : 機器効率, $E_{d, t}$ : 電力需要, $H W_{d, t}$ : 給湯需要, $C a p^{*}$ : 機器容量

[内生変数]

$T_{d, t}$ : 貯湯量, $D_{d, t}$ : 温水排気量

[添字・肩字]

$P_{e}:$ PEFC の発電, $P_{h w}:$ PEFC の排熱回収, $T$ : 販湯槽,

\section{3. 追加条件の適用頻度}

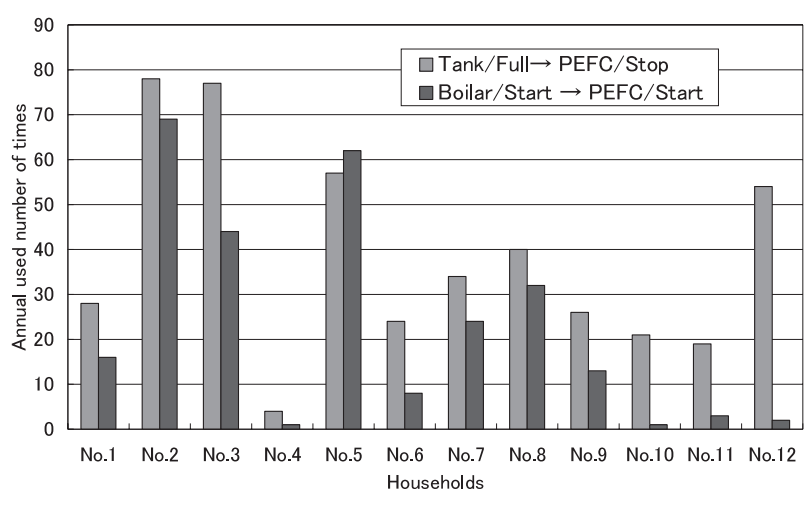

付図 2 追加条件の適用回数

app.Fig.2. A number of applications of additional condition.
山 岸 由 佳 (学生員) 1983 年 11 月 14 日生。 2006 年 3 月大

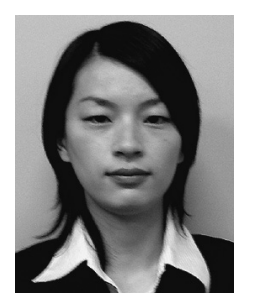
阪大学工学部電子情報エネルギー工学科卒業。同 年 4 月同大学大学院工学研究科電気電子情報工学 専攻入学, 現在に至る。主として, 住宅用コージェ ネレーションシステムの運用手法の研究に従事。 
杉 原 英 治 (正員) 2000 年 3 月北海道大学大学院工学研究 科博士後期課程修了。同年 4 月大阪大学大学院工 学研究科リサーチアソシエイト, 同助手を経て, 2006 年 3 月同助教授となり，現在に至る。博士 (工学)。主に電力系統及びエネルギーシステムの モデル分析に関する研究に従事。エネルギー・資 源学会会員。

佐 伯

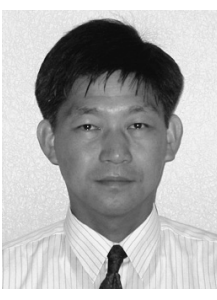

修（正員） 1987 年 3 月大阪大学工学部電気工学科 卒業。1989 年 3 月大阪大学大学院工学研究科電 気工学専攻博士前期課程修了。現在, 大阪大学大 学院工学研究科助手。主として電力・エネルギー システムの最適化手法に関する研究に従事。シス テム制御情報学会，エネルギー・資源学会，IEEE などの会員。
辻

毅一郎（正員） 1968 年 3 月大阪大学大学院工学研究科電

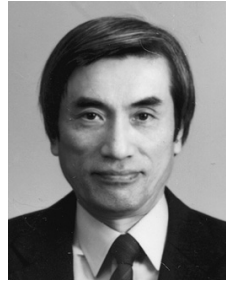
気工学専攻修士課程修了。1973 年 6 月 Case Western Reserve 大学大学院システム工学専攻博士課程 修了。同年 8 月大阪大学工学部電気工学科助手, 同講師，同助教授を経て，1988 年 12 月同教授。 2007 年 8 月大阪大学理事となり, 現在に至る。こ の間, 一時国際応用システム解析研究所 (IIASA) 研究員。Ph.D.。主に応用システム分析に関する 研究に従事。IEEE，エネルギー・資源学会，システム制御情報学会， 計測自動制御学会会員。 